\title{
Tandem Mass Spectrometry of Metal Nitrate Negative Ions Produced by Electrospray Ionization
}

\author{
Fumin Li, Matthew A. Byers, and R. S. Houk \\ Department of Chemistry, Ames Laboratory, United States Department of Energy, Iowa State University, \\ Ames, Iowa, USA
}

\begin{abstract}
$\mathrm{M}\left(\mathrm{NO}_{3}\right)_{\mathrm{x}}^{-}$ions are generated by electrospray ionization (ESI) of metal solutions in nitric acid in negative ion mode. Collision-induced reactions of these ions are monitored in a tandem mass spectrometer (MS) of quadrupole-octopole-quadrupole (QoQ) geometry. For Group 1and 2 elements, the $\mathrm{M}\left(\mathrm{NO}_{3}\right)_{\mathrm{x}}^{-}$ions dissociate into $\mathrm{NO}_{3}^{-}$and neutral metal nitrate molecules. These elements also form some $\mathrm{M}_{x}\left(\mathrm{NO}_{3}\right)_{x+1}^{-}$clusters, especially $\mathrm{Li}^{+}$. Metal nitrate ions from transition elements and Group 13 elements fragment into oxo products and also undergo internal electron transfer to leave the $\mathrm{M}$ atom in a lower oxidation state. To calibrate the collision energy, the dissociation energy of $\mathrm{O}-\mathrm{NO}_{2}^{-}$is found to be $5.55 \mathrm{eV}$, about $0.76 \mathrm{eV}$ lower than a value derived from thermochemistry. The product ions from $\mathrm{Fe}\left(\mathrm{NO}_{3}\right)_{4}^{-}$ions have low formation thresholds of only 0.5 to $2 \mathrm{eV}$. (J Am Soc Mass Spectrom 2003, 14, 671-679) (C) 2003 American Society for Mass Spectrometry
\end{abstract}

A fter the pioneering studies of Yamashita and Fenn [1], ESI-MS has revolutionized the analysis of biological molecules [2-5]. This method also provides valuable information about inorganic and organometallic compounds [6-8] and the interactions and binding of metal ions to biological molecules [9-11]. The use of high mass resolution allows identification of the metal atom [12] and even its oxidation state [13] using intact metal-protein ions.

Most studies of small inorganic ions have been done in positive ion mode [14-18]. Many metal-solvent clusters, e.g., $\mathrm{M}^{x+}\left(\mathrm{H}_{2} \mathrm{O}\right)_{n}, n=1$ to 6 , are typically formed under "soft" ion extraction conditions [7, 17, 18]. Highly charged metal ions tend to react with solvent molecules to yield hydroxy or methoxy ions when energetic collision conditions are used to remove solvent during ion extraction. Preserving the original form of the metal ion in positive mode generally requires element-specific optimization of ion extraction conditions and leads to a variety of ion-solvent clusters.

Previous work from our group [19] showed that an excess of nitric acid can be used to produce $\mathrm{M}\left(\mathrm{NO}_{3}\right)_{\mathrm{x}}^{-}$ ions in negative ion mode. A single set of ion extraction conditions yields these ions for many elements. This early work was done with only one stage of MS. The present work reports collision-induced dissociation (CID) reactions of these $\mathrm{M}\left(\mathrm{NO}_{3}\right)_{\mathrm{x}}^{-}$ions in a triple

Published online May 13, 2003

Address reprint requests to Dr. R. S. Houk, Department of Chemistry, Ames Laboratory, United States Department of Energy, Iowa State University, Ames, IA 50011, USA. E-mail: rshouk@iastate.edu "quadrupole" MS, actually a QoQ instrument. The properties of these ions are relevant in a number of areas. Nitrate is an important agricultural material and can be a pollutant. Nitrate and nitric acid cluster ions are also the main negative charge carriers in certain regions of the Earth's atmosphere [20(a), 20(b)]. The related neutral compounds $\mathrm{NO}_{2}$ and $\mathrm{NO}_{3}$ and their acids $\mathrm{HNO}_{2}$ and $\mathrm{HNO}_{3}$ are also important atmospheric species [21]. Metal nitrate compounds are used as explosives; Zhao and Yinon [22] recently described ESI mass spectra and CID properties of complexes and clusters of alkali metals and ammonium with various anions, including nitrate.

\section{Experimental}

\section{Samples and Sample Preparation}

Concentrated nitric acid was purchased from J. T. Baker (Phillipsburg, NJ) and used without further purification. Aliquots of the concentrated acid were mixed with HPLC grade methanol and deionized water (18 M $\Omega$, Barnstead Nanopure, Newton, MA) to form a solvent of $0.05 \%$ nitric acid in $25 \%$ water: $75 \%$ methanol. Aliquots of aqueous, acidic metal stock solutions (1000 ppm, Spex Certiprep, Metuchen, NJ ) were diluted with solvent to the desired concentrations.

\section{ESI-MS}

A triple quadrupole MS (TSQ 7000, Thermo Finnigan, San Jose, CA, $m / z$ range 10 to 2500 ) equipped with an 


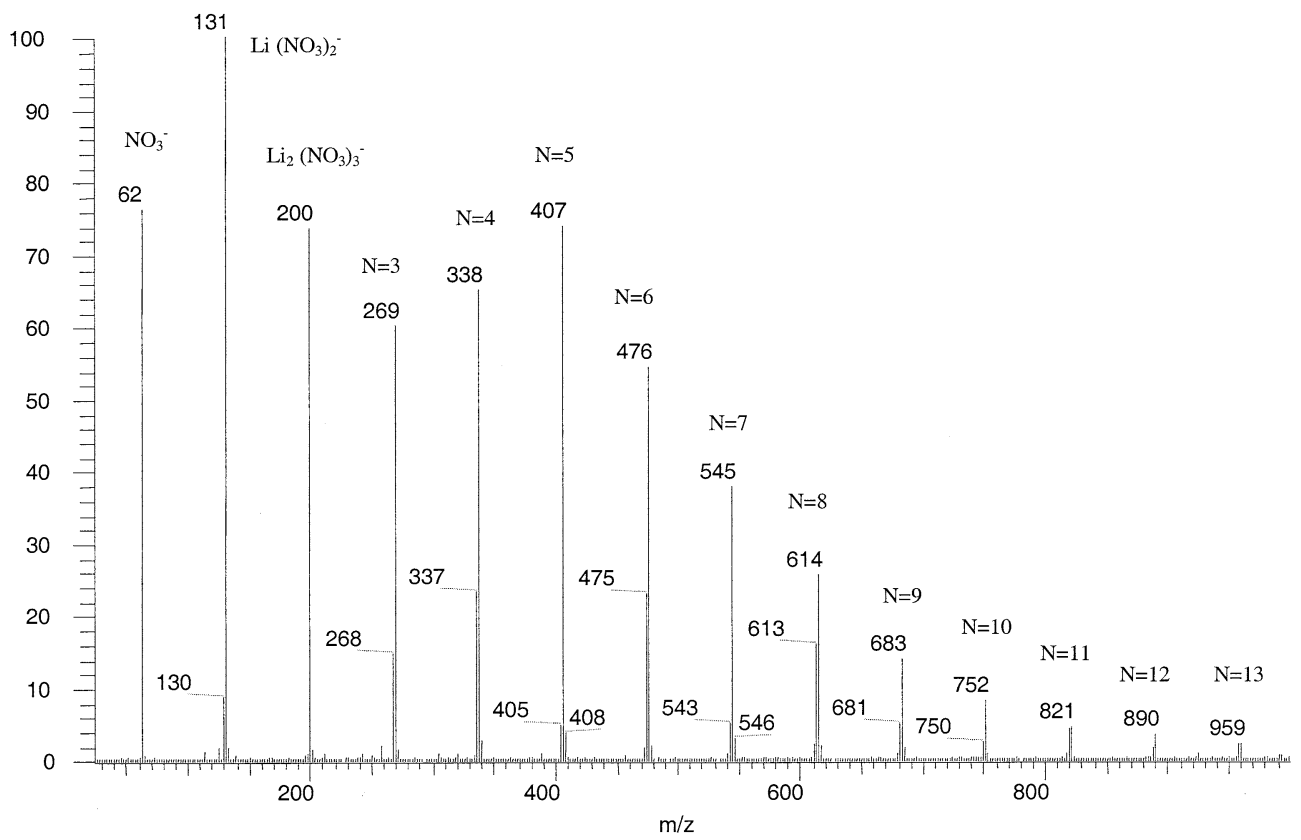

Figure 1. Mass spectrum of $0.1 \mathrm{mM} \mathrm{Li}$ in $25 / 75$ water/methanol solvent with $0.05 \% \mathrm{HNO}_{3}$. Cluster ions $\mathrm{Li}_{n}\left(\mathrm{NO}_{3}\right)_{n+1}^{-}(n=1-13)$ are observed.

on-axis electrospray source was used. Solutions were infused continuously with a syringe pump $(5 \mu \mathrm{L} / \mathrm{min}$, Model 22, Harvard Apparatus, Southnatic MA). Nitrogen (60 psi) and high-purity Ar were used as nebulizing gas and collision gas, respectively. The ESI capillary voltage was $-2.5 \mathrm{kV}$, and the heated capillary was kept at $250{ }^{\circ} \mathrm{C},-5 \mathrm{~V}$. The ring electrode, skimmer and first octopole were at $-4.7,0$, and $+3 \mathrm{~V}$, respectively. The pressure in the gas line into the octopole collision cell was usually $0.13 \mathrm{~Pa}$ but was reduced to $0.026 \mathrm{~Pa}$ for threshold measurements. The collision energies (i.e., potential offsets between grounded skimmer and collision cell) were 10 to $30 \mathrm{eV}$ (lab frame) for normal tandem MS and 3 to $43 \mathrm{eV}$ for single reaction mode (SRM) experiments. The resolution of the first mass analyzer was reduced deliberately to obtain better signals in tandem MS experiments.

\section{Results and Discussion}

\section{Comparison of Ion Extraction Methods}

In the previous work, a PE Sciex API1 instrument was used; ions were extracted through a single, thin metal orifice (250 $\mu \mathrm{m}$ diameter) directly through a supersonic jet and into RF only rods at a background pressure of $\sim 1 \mathrm{mPa}$. During ion extraction, the ions underwent collisions only with the $\mathrm{N}_{2}$ in the curtain gas and supersonic jet. Few collisions with the metal walls are expected with this extraction device.

The Finnigan TSQ 7000 (San Jose, CA) used in the present work has a heated capillary interface. Here the ions are entrained in gas flow through a long, thin stainless steel tube (114 mm long $\times 400 \mu \mathrm{m}$ i.d.). The ions then pass through a supersonic expansion and skimmer into an octopole ion guide, which transports the ions into a third chamber housing the MS.

In general, it is much more difficult to observe metal chloride ions $\mathrm{MCl}_{x}^{-}$using the heated capillary interface. $\mathrm{M}\left(\mathrm{NO}_{3}\right)_{\mathrm{x}}^{-}$ions often dominate even if the sample contains no $\mathrm{HNO}_{3}$ and percent levels of $\mathrm{HCl}$. Recent measurements on a API 3000 triple quadrupole instrument at PE Sciex corroborate these observations [23]. In wet atmospheric aerosols, nitric acid sticks readily to surfaces and displaces $\mathrm{HCl}$, with replacement by $\mathrm{HNO}_{3}$. Sea salt particles of sodium chloride can be converted to sodium nitrate in this fashion [21]. Perhaps analogous processes occur during droplet production, desolvation, or ion extraction in ESI, especially when the ions pass through a long, narrow tube in a heated capillary extraction device.

MS and CID of Nitrate Complexes of Group 1 and 2 Metals

A mass spectrum for a Li sample is shown in Figure 1. Nitrate monomer $\left(\mathrm{NO}_{3}^{-}, m / z=62\right)$ and protonated dimer $\left(\mathrm{H}\left(\mathrm{NO}_{3}\right)_{2}^{-}, m / z=125\right)$ are the main background ions. Alkali metals are singly charged in solution and thus yield $\mathrm{M}\left(\mathrm{NO}_{3}\right)_{2}^{-}$ions.

A typical CID product ion spectrum is shown for $\mathrm{Li}\left(\mathrm{NO}_{3}\right)_{2}^{-}$in Figure 2. Nitrate is the only product ion observed from CID of any Group $1 \mathrm{M}\left(\mathrm{NO}_{3}\right)_{2}^{-}$species. Presumably, the remaining products are neutral $\mathrm{MNO}_{3}$ molecules. The only CID reaction for these ions can be written as follows: 


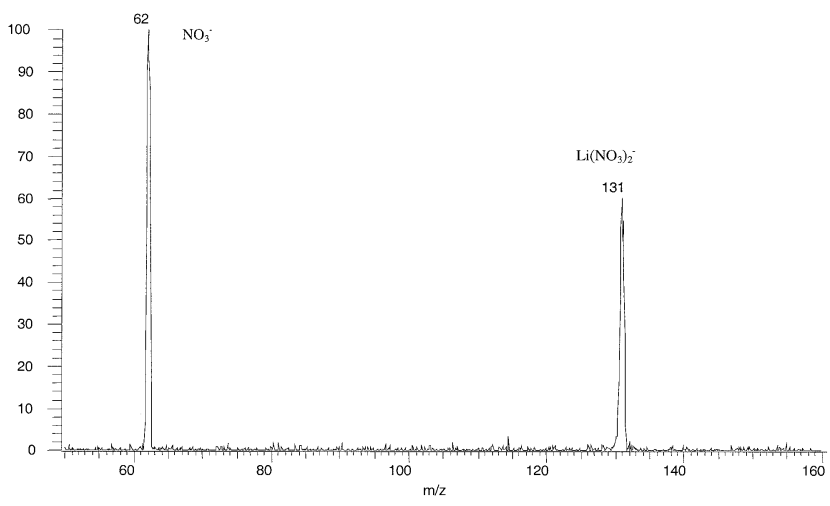

Figure 2. CID product spectrum of $\mathrm{Li}\left(\mathrm{NO}_{3}\right)_{2}^{-}(\mathrm{m} / \mathrm{z} 131)$, which fragments into $\mathrm{LiNO}_{3}$ and $\mathrm{NO}_{3}^{-}$. The collision energy and collision gas pressure were $15 \mathrm{eV}$ lab and $0.13 \mathrm{~Pa}$.

$$
\mathrm{M}\left(\mathrm{NO}_{3}\right)_{2}^{-} \rightarrow \mathrm{NO}_{3}^{-}+\mathrm{MNO}_{3}
$$

The neutral $\mathrm{MNO}_{3}$ species is shown in italics here and in subsequent reactions to indicate that its formation is inferred but not observed directly.

As shown for Li in Figure 1, a variety of cluster ions with several metal atoms are also observed. These cluster ions have the general formula $\mathrm{M}_{x}\left(\mathrm{NO}_{3}\right)_{x+1}^{-}$and are especially abundant for $\mathrm{Li}$, less so for $\mathrm{Na}$ and other, heavier alkali metal ions. For example, $\mathrm{Li}_{x}\left(\mathrm{NO}_{3}\right)_{x+1}^{-}(x>$ 1) clusters are $82 \%$ of the total $\mathrm{Li}$ ions observed and progress to $x=13$ (Figure 1 ), $\mathrm{Na}_{x}\left(\mathrm{NO}_{3}\right)_{x+1}^{-}$clusters are $71 \%$ of the total $\mathrm{Na}$ ions seen and stop at $x=8$ (data not shown), while $\mathrm{Cs}\left(\mathrm{NO}_{3}\right)_{2}^{-}, \quad \mathrm{Cs}_{2}\left(\mathrm{NO}_{3}\right)_{3}^{-} \quad(17 \%)$ and $\mathrm{Cs}_{3}\left(\mathrm{NO}_{3}\right)_{4}^{-}(4 \%)$ are the only $\mathrm{Cs}$ nitrate species seen (data not shown). These cluster ions are also much more abundant from the heated capillary interface than from the curtain gas interface used previously [19]. In general, the intensity distributions of the $\mathrm{Li}$ isotope peaks in the cluster ions correspond to the expected patterns, as shown by the measured and calculated spectra for $\mathrm{Li}_{8}\left(\mathrm{NO}_{3}\right)_{9}^{-}$in Figure 3.

A product ion spectrum from CID of the cluster

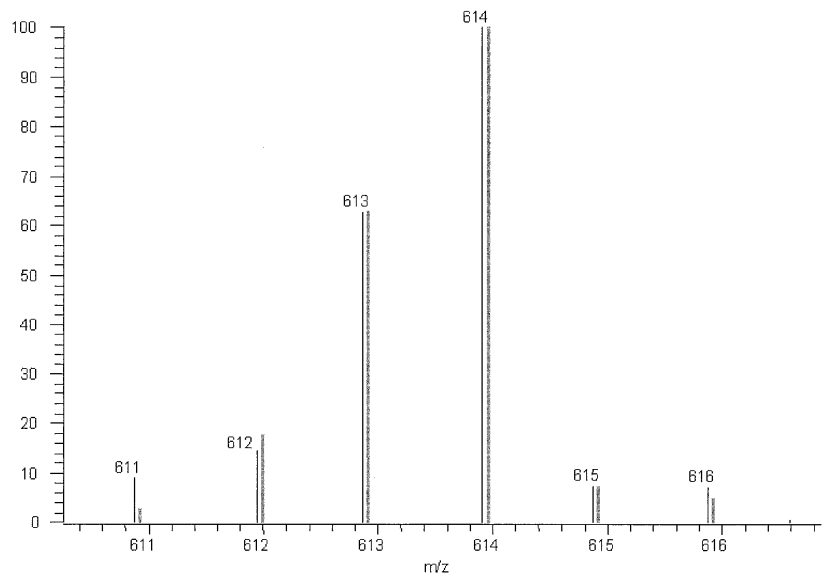

Figure 3. Expanded scan of isotope peaks of $\mathrm{Li}_{8}\left(\mathrm{NO}_{3}\right)_{9}^{-}$. Thin black lines are the measured intensities, gray bars are the calculated isotope distributions.

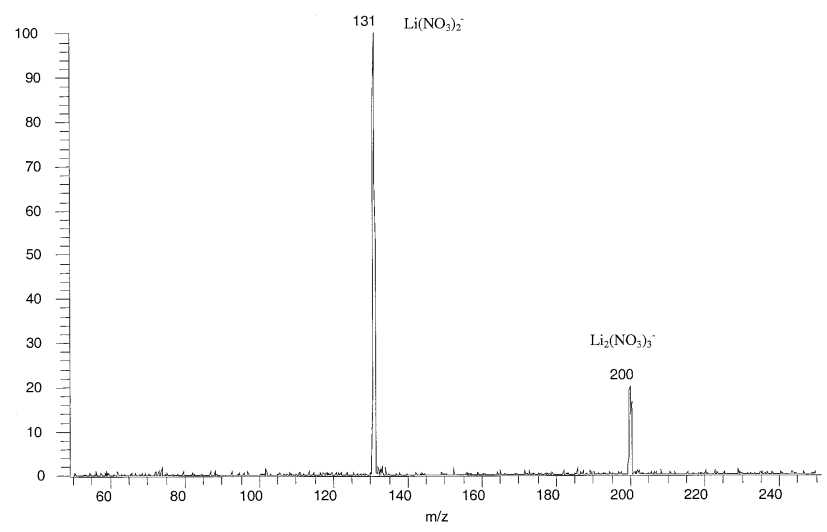

Figure 4. CID product spectrum of $\mathrm{Li}_{2}\left(\mathrm{NO}_{3}\right)_{3}^{-}(\mathrm{m} / \mathrm{z} 200)$, which fragments into $\mathrm{Li}\left(\mathrm{NO}_{3}\right)_{2}^{-}$and $\mathrm{LiNO}_{3}$. Note that $\mathrm{Li}_{2}\left(\mathrm{NO}_{3}\right)_{3}^{-}$does not make $\mathrm{NO}_{3}^{-}$directly. The collision energy and collision gas pressure were $10 \mathrm{eV}$ lab and $0.10 \mathrm{~Pa}$.

$\mathrm{Li}_{2}\left(\mathrm{NO}_{3}\right)_{3}^{-}$is shown in Figure 4 . The only ionic product is the next lower species $\mathrm{Li}\left(\mathrm{NO}_{3}\right)_{2}^{-}$; nitrate is not formed. CID of the larger lithium nitrate clusters yields various $\mathrm{Li}_{x}\left(\mathrm{NO}_{3}\right)_{x+1}^{-}$products, in decreasing abundance as more $\mathrm{LiNO}_{3}$ molecules are lost (Figure 5). Again, no free $\mathrm{NO}_{3}^{-}$is formed from metal nitrate clusters with more than one metal atom.

The Group 2 metals give primarily $\mathrm{M}\left(\mathrm{NO}_{3}\right)_{3}^{-}$ions, with some $\mathrm{M}_{2}\left(\mathrm{NO}_{3}\right)_{5}^{-}$clusters (Figure 6 ), as expected for metal ions in the $2+$ oxidation state. On CID the $\mathrm{M}\left(\mathrm{NO}_{3}\right)_{3}^{-}$ions give only $\mathrm{NO}_{3}^{-}$, and the $\mathrm{M}_{2}\left(\mathrm{NO}_{3}\right)_{5}^{-}$ clusters give only $\mathrm{M}\left(\mathrm{NO}_{3}\right)_{3}^{-}$(Figure 7 ).

$$
\begin{aligned}
& \mathrm{M}\left(\mathrm{NO}_{3}\right)_{3}^{-} \rightarrow \mathrm{NO}_{3}^{-}+\mathrm{M}\left(\mathrm{NO}_{3}\right)_{2} \\
& \mathrm{M}_{2}\left(\mathrm{NO}_{3}\right)_{5}^{-} \rightarrow \mathrm{M}\left(\mathrm{NO}_{3}\right)_{3}^{-}+\mathrm{M}\left(\mathrm{NO}_{3}\right)_{2}
\end{aligned}
$$

These ions thus behave like those from the Group 1 metals. No $\mathrm{M}^{\mathrm{I}}\left(\mathrm{NO}_{3}\right)_{2}^{-}$ions are formed, i.e., the $\mathrm{M}^{2+}$ ion is not reduced during CID reactions of $\mathrm{M}^{\mathrm{II}}\left(\mathrm{NO}_{3}\right)_{3}^{-}$for the Group 2 elements.

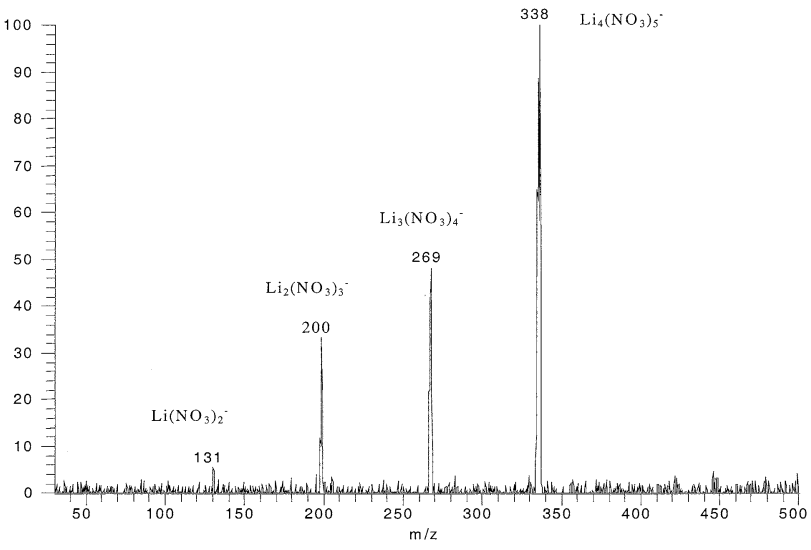

Figure 5. CID product spectrum of $\mathrm{Li}_{4}\left(\mathrm{NO}_{3}\right)_{5}^{-}(\mathrm{m} / \mathrm{z}=338)$, which fragments into various $\mathrm{Li}$ nitrate clusters, but not $\mathrm{NO}_{3}^{-}$. The collision energy and collision pressure were $22 \mathrm{eV} \mathrm{lab}$ and $0.10 \mathrm{~Pa}$, respectively. 


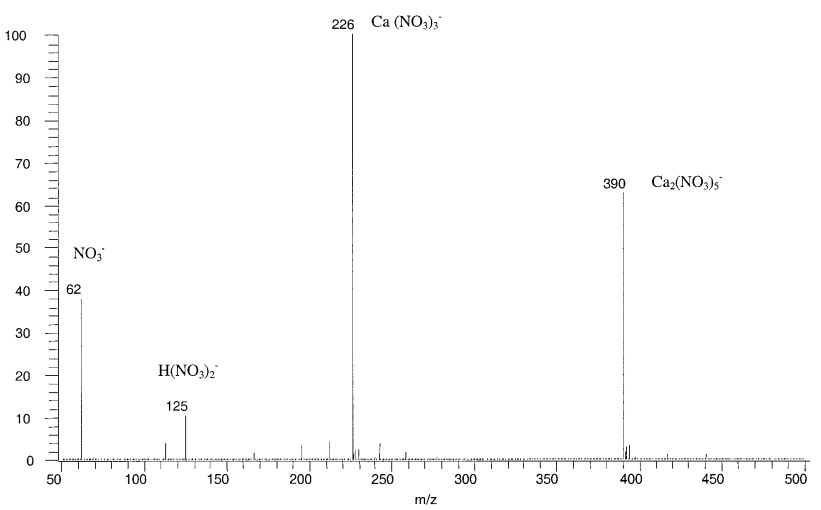

Figure 6. Mass spectrum of $0.1 \mathrm{mM} \mathrm{Ca}$ in $25 / 75$ water/methanol solvent with $0.05 \% \mathrm{HNO}_{3}$. $\mathrm{Ca}\left(\mathrm{NO}_{3}\right)_{3}^{-}(\mathrm{m} / \mathrm{z}=226)$ and $\mathrm{Ca}_{2}\left(\mathrm{NO}_{3}\right)_{5}^{-}$ $(\mathrm{m} / \mathrm{z}=390)$ were observed.

\section{MS and CID of Nitrate Complexes of Transition Metals and Group 13 Metals}

In the previous paper, $3+$ metal ions in solution gave mainly $\mathrm{M}\left(\mathrm{NO}_{3}\right)_{4}^{-}$ions. Those elements with a stable $2+$ oxidation state in solution were also seen as $\mathrm{M}\left(\mathrm{NO}_{3}\right)_{3}^{-}$ ions [19]. With the present system, more in-source fragmentation is observed, as shown in the spectrum for $\mathrm{Fe}^{3+}$ in Figure 8. While $\mathrm{Fe}\left(\mathrm{NO}_{3}\right)_{4}^{-}$is the most abundant ion from the $\mathrm{Fe}^{3+}$ sample, there is a substantial amount of the oxo product $\mathrm{FeO}\left(\mathrm{NO}_{3}\right)_{3}^{-}$and also $\mathrm{Fe}\left(\mathrm{NO}_{3}\right)_{3}^{-}$. A small amount of the cluster $\mathrm{Fe}{ }_{2} \mathrm{O}\left(\mathrm{NO}_{3}\right)_{5}^{-}$is observed. The assignment of this ion is confirmed by the expanded view of the spectrum in Figure 9. The signal ratio for $(\mathrm{m} / \mathrm{z} 436 / \mathrm{m} / \mathrm{z} 438)$ is 0.12 , in approximate agreement with the value of 0.126 expected for a species with $\mathrm{Fe}_{2}$ stoichiometry.

The various ions observed and their CID reactions are summarized in Table 1. A typical product ion spectrum is shown for $\mathrm{Y}\left(\mathrm{NO}_{3}\right)_{4}^{-}$in Figure 10. The product ions are similar to the fragments observed just from CID in the ESI source. For example, the CID spectrum of $\mathrm{Fe}\left(\mathrm{NO}_{3}\right)_{4}^{-}$looks much like the source spectrum in Figure 8, without the cluster $\mathrm{Fe}_{2} \mathrm{O}\left(\mathrm{NO}_{3}\right)_{5}^{-}$, of course.

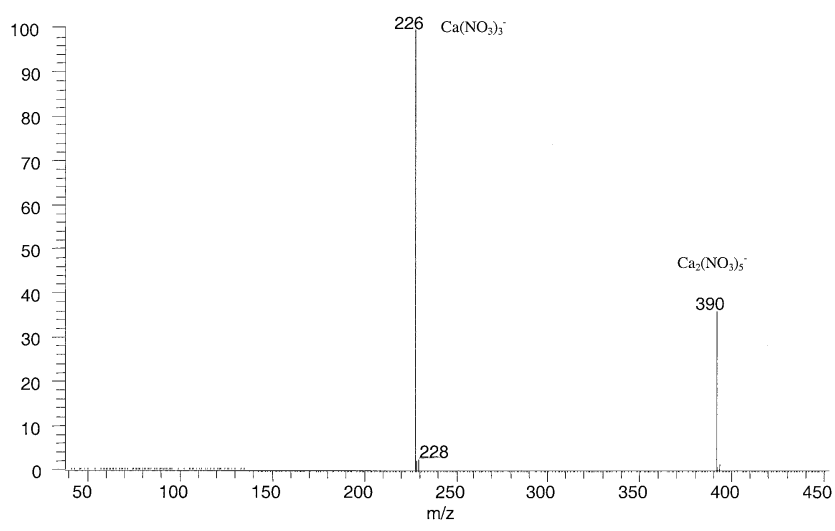

Figure 7. CID product spectrum of $\mathrm{Ca}_{2}\left(\mathrm{NO}_{3}\right)_{5}^{-}(\mathrm{m} / \mathrm{z}=390)$, which fragments into $\mathrm{Ca}\left(\mathrm{NO}_{3}\right)_{2}$ and $\mathrm{Ca}\left(\mathrm{NO}_{3}\right)_{3}^{-}$. Collision energy and pressure are $20 \mathrm{eV} \mathrm{lab}$ and $0.13 \mathrm{~Pa}$.

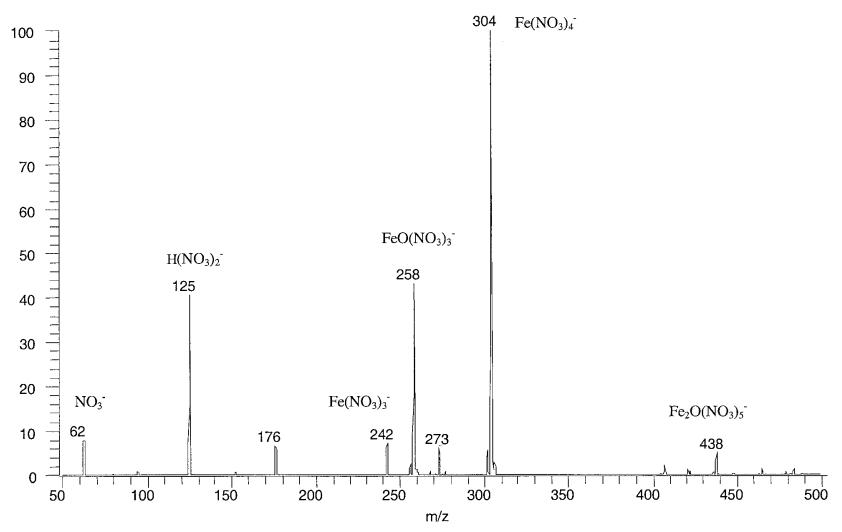

Figure 8. Mass spectrum of $50 \mathrm{ppm} \mathrm{Fe} \mathrm{in} \mathrm{25/75} \mathrm{water/methanol}$ solvent with $0.05 \% \mathrm{HNO}_{3}$. The major ions are $\mathrm{Fe}\left(\mathrm{NO}_{3}\right)_{4}^{-}(\mathrm{m} / z$ 304), $\mathrm{FeO}\left(\mathrm{NO}_{3}\right)_{3}^{-}(\mathrm{m} / z$ 258) due to in-source fragmentation, and some $\mathrm{Fe}^{\mathrm{II}}\left(\mathrm{NO}_{3}\right)_{3}^{-}(m / z 242)$ from reduction of $\mathrm{Fe}^{\mathrm{III}}\left(\mathrm{NO}_{3}\right)_{4}^{-}$. See next figure for enlargement of region around $m / z=438$.

In general, the CID products observed correspond to the following reactions, which can occur either in the source and/or during CID in the collision cell. Again, the neutral molecules written in italics are identified by implication; they are not observed directly.

1. Elimination of $\mathrm{NO}_{2}$ with formation of oxo-nitrate complex.

$$
\begin{aligned}
& \mathrm{M}\left(\mathrm{NO}_{3}\right)_{4}^{-} \rightarrow \mathrm{MO}\left(\mathrm{NO}_{3}\right)_{3}^{-}+\mathrm{NO}_{2} \\
& \rightarrow \mathrm{MO}_{2}\left(\mathrm{NO}_{3}\right)_{2}^{-}+2 \mathrm{NO}_{2} \\
& \rightarrow \mathrm{MO}_{3}\left(\mathrm{NO}_{3}\right)^{-}+3 \mathrm{NO}_{2}
\end{aligned}
$$

These reactions are favored for early transition metals but occur to some extent for $\mathrm{Cu}^{2+}$ and $\mathrm{Zn}^{2+}$ as well. Initially, we felt the metal atom was oxidized to higher oxidation states during these reactions. For example, the $\mathrm{Fe}$ atom in $\mathrm{FeO}\left(\mathrm{NO}_{3}\right)_{3}^{-}$could be considered to be in the +4 state, if $\mathrm{O}$ is present as the conventional $\mathrm{O}^{2-}$. However, the ionization energy of $\mathrm{Fe}^{3+}$ is almost $55 \mathrm{eV}$

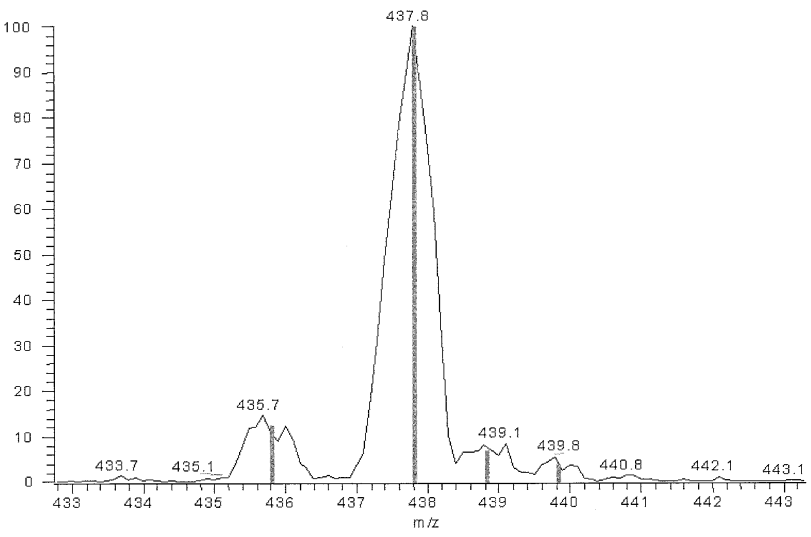

Figure 9. Expanded scan of region containing $\mathrm{Fe}_{2} \mathrm{O}\left(\mathrm{NO}_{3}\right)_{5}^{-}$ions. The gray bars show the calculated isotope distribution for the four most abundant ions at $\mathrm{m} / \mathrm{z} 435.81(12.64 \%), 437.81(100 \%), 438.81$ (7.01\%), and $439.81(3.98 \%)$. 
Table 1. CID reactions of nitrate complexes of transition metal and Group 13 metal ions

\begin{tabular}{|c|c|}
\hline Metal complex/parent & Product(s)/Reactions \\
\hline $\mathrm{Sc}\left(\mathrm{NO}_{3}\right)_{4}^{-}$ & $\begin{array}{l}\mathrm{Sc}\left(\mathrm{NO}_{3}\right)_{4}^{-} \rightarrow \mathrm{ScO}\left(\mathrm{NO}_{3}\right)_{3}^{-}+\mathrm{NO}_{2} \\
\mathrm{Sc}\left(\mathrm{NO}_{3}\right)_{4}^{-} \rightarrow \mathrm{ScO}_{2}\left(\mathrm{NO}_{3}\right)_{2}^{-}+2 \mathrm{NO}_{2} \\
\mathrm{Sc}\left(\mathrm{NO}_{3}\right)_{4}^{-} \rightarrow \mathrm{NO}_{3}^{-}+\mathrm{Sc}\left(\mathrm{NO}_{3}\right)_{3} \\
\mathrm{Cr}\left(\mathrm{NO}_{3}\right)_{4}^{-} \rightarrow \mathrm{CrO}\left(\mathrm{NO}_{3}\right)_{3}^{-}+\mathrm{NO}_{2}\end{array}$ \\
\hline $\mathrm{Cr}\left(\mathrm{NO}_{3}\right)_{4}^{-}$ & $\begin{array}{l}\mathrm{Cr}\left(\mathrm{NO}_{3}\right)_{4}^{-} \rightarrow \mathrm{CrO}_{2}\left(\mathrm{NO}_{3}\right)_{2}^{-}+2 \mathrm{NO}_{2} \\
\mathrm{Cr}\left(\mathrm{NO}_{3}\right)_{4}^{-} \rightarrow \mathrm{CrO}_{3}\left(\mathrm{NO}_{3}\right)^{-}+3 \mathrm{NO}_{2} \\
\mathrm{Cr}\left(\mathrm{NO}_{3}\right)_{4}^{-} \rightarrow \mathrm{NO}_{3}^{-}+\mathrm{Cr}\left(\mathrm{NO}_{3}\right)_{3} \\
\mathrm{Mn}\left(\mathrm{NO}_{3}\right)_{3}^{-} \rightarrow \mathrm{MnO}\left(\mathrm{NO}_{3}\right)_{2}^{-}+\mathrm{NO}_{2}\end{array}$ \\
\hline $\mathrm{Mn}\left(\mathrm{NO}_{3}\right)_{3}^{-}$ & $\begin{array}{l}\mathrm{Mn}\left(\mathrm{NO}_{3}\right)_{3}^{-} \rightarrow \mathrm{MnO}_{2}\left(\mathrm{NO}_{3}\right)^{-}+2 \mathrm{NO}_{2} \\
\mathrm{Mn}\left(\mathrm{NO}_{3}\right)_{3}^{-} \rightarrow \mathrm{NO}_{3}^{-}+\mathrm{Mn}\left(\mathrm{NO}_{3}\right)_{2} \\
\mathrm{Fe}\left(\mathrm{NO}_{3}\right)_{4}^{-} \rightarrow \mathrm{FeO}\left(\mathrm{NO}_{3}\right)_{3}^{-}+\mathrm{NO}_{2} \\
\mathrm{Fe}\left(\mathrm{NO}_{3}\right)_{4}^{-} \rightarrow \mathrm{FeO}_{2}\left(\mathrm{NO}_{3}\right)_{2}^{-}+2 \mathrm{NO}_{2}\end{array}$ \\
\hline $\mathrm{Fe}\left(\mathrm{NO}_{3}\right)_{4}^{-}$ & $\begin{array}{l}\mathrm{Fe}\left(\mathrm{NO}_{3}\right)_{4}^{-} \rightarrow \mathrm{FeO}_{3}\left(\mathrm{NO}_{3}\right)^{-}+3 \mathrm{NO}_{2} \\
\mathrm{Fe}\left(\mathrm{NO}_{3}\right)_{4}^{-} \rightarrow \mathrm{NO}_{3}^{-}+\mathrm{Fe}\left(\mathrm{NO}_{3}\right)_{3} \\
\mathrm{Fe} \\
\mathrm{FeO}\left(\mathrm{NO}_{3}\right)_{4}^{-1} \rightarrow \mathrm{FE}_{3}^{-1 I}\left(\mathrm{NO}_{3}\right)_{3}^{-}+\mathrm{NeO}_{2}\left(\mathrm{NO}_{3}\right)_{2}^{-}+\mathrm{NO}_{2}\end{array}$ \\
\hline $\mathrm{FeO}\left(\mathrm{NO}_{3}\right)_{3}^{-}$ & $\begin{array}{l}\mathrm{FeO}\left(\mathrm{NO}_{3}\right)_{3}^{-} \rightarrow \mathrm{FeO}_{3}\left(\mathrm{NO}_{3}\right)^{-}+2 \mathrm{NO}_{2} \\
\mathrm{Fe}\left(\mathrm{NO}_{3}\right)_{3}^{-} \rightarrow \mathrm{FeO}\left(\mathrm{NO}_{3}\right)_{2}^{-}+\mathrm{NO}_{2}\end{array}$ \\
\hline $\mathrm{Fe}\left(\mathrm{NO}_{3}\right)_{3}^{-}$ & $\begin{array}{l}\mathrm{Fe}\left(\mathrm{NO}_{3}\right)_{3}^{-} \rightarrow \mathrm{FeO}_{2}\left(\mathrm{NO}_{3}\right)^{-}+2 \mathrm{NO}_{2} \\
\mathrm{Fe}\left(\mathrm{NO}_{3}\right)_{3}^{-} \rightarrow \mathrm{NO}_{3}^{-}+\mathrm{Fe}\left(\mathrm{NO}_{2}\right)_{2} \\
\mathrm{Co}\left(\mathrm{NO}_{3}\right)_{3}^{-} \rightarrow \mathrm{CoO}\left(\mathrm{NO}_{3}\right)_{2}^{-}+\mathrm{NO}_{2} \\
\mathrm{Co}\left(\mathrm{NO}_{3}\right)_{3}^{-} \rightarrow \mathrm{NO}_{3}^{-}+\mathrm{Co}\left(\mathrm{NO}_{3}\right)_{2}\end{array}$ \\
\hline $\mathrm{Ni}\left(\mathrm{NO}_{3}\right)_{3}^{-}$ & $\begin{array}{l}\mathrm{Ni}\left(\mathrm{NO}_{3}\right)_{3}^{-} \rightarrow \mathrm{NiO}\left(\mathrm{NO}_{3}\right)_{2}^{-}+\mathrm{NO}_{2} \\
\mathrm{Ni}\left(\mathrm{NO}_{3}\right)_{3}^{-} \rightarrow \mathrm{NO}_{3}^{-}+\mathrm{Ni}\left(\mathrm{NO}_{3}\right)_{2} \\
\mathrm{Cu}\left(\mathrm{NO}_{3}\right)_{3}^{-} \rightarrow \mathrm{Cu}^{\prime}\left(\mathrm{NO}_{3}\right)_{2}^{-}+\mathrm{NO}_{3} \\
\mathrm{Cu}^{\prime \prime}\left(\mathrm{NO}_{3}\right)_{3}^{-} \rightarrow \mathrm{NO}_{3}^{-}+\mathrm{Cu}\left(\mathrm{NO}_{3}\right)_{2} \\
\mathrm{Cu}^{\prime}\left(\mathrm{NO}_{3}\right)_{2}^{-} \rightarrow \mathrm{Cu}^{\prime} \mathrm{O}\left(\mathrm{NO}_{3}\right)^{-}+\mathrm{NO}_{2} \\
\mathrm{Cu}\left(\mathrm{NO}_{3}\right)_{2}^{-} \rightarrow \mathrm{NO}_{3}^{-}+\mathrm{Cu}^{\prime}\left(\mathrm{NO}_{3}\right)\end{array}$ \\
\hline $\mathrm{Zn}\left(\mathrm{NO}_{3}\right)_{3}^{-}$ & $\begin{array}{l}\mathrm{Zn}\left(\mathrm{NO}_{3}\right)_{3}^{-} \rightarrow \mathrm{ZnO}\left(\mathrm{NO}_{3}\right)_{2}^{-}+\mathrm{NO}_{2} \\
\mathrm{Zn}\left(\mathrm{NO}_{3}\right)_{3}^{-} \rightarrow \mathrm{NO}_{3}^{-}+\mathrm{Zn}\left(\mathrm{NO}_{3}\right)_{2} \\
\mathrm{Fe}_{2} \mathrm{O}\left(\mathrm{NO}_{3}\right)_{5}^{-} \rightarrow \mathrm{Fe}_{2} \mathrm{O}_{2}\left(\mathrm{NO}_{3}\right)_{4}^{-}+\mathrm{NO}_{2}\end{array}$ \\
\hline $\mathrm{Fe}_{2} \mathrm{O}\left(\mathrm{NO}_{3}\right)_{5}^{-}$ & $\begin{array}{l}\mathrm{Fe} e_{2} \mathrm{O}\left(\mathrm{NO}_{3}\right)_{5}^{-} \rightarrow \mathrm{Fe}_{2} \mathrm{O}_{3}\left(\mathrm{NO}_{3}\right)_{3}^{-}+2 \mathrm{NO}_{2} \\
\mathrm{Fe} \mathrm{O}_{2} \mathrm{O}\left(\mathrm{NO}_{3}\right)_{5}^{-} \rightarrow \mathrm{Fe}_{2} \mathrm{O}_{4}\left(\mathrm{NO}_{3}\right)_{2}^{-}+3 \mathrm{NO}_{2} \\
\mathrm{Y}\left(\mathrm{NO}_{3}\right)_{4}^{-} \rightarrow \mathrm{YO}\left(\mathrm{NO}_{3}\right)_{3}^{-}+\mathrm{NO}_{2} \\
\mathrm{Y}\left(\mathrm{NO}_{3}\right)_{4}^{-} \rightarrow \mathrm{YO}_{2}\left(\mathrm{NO}_{3}\right)_{2}^{-}+2 \mathrm{NO}_{2}\end{array}$ \\
\hline $\mathrm{Y}\left(\mathrm{NO}_{3}\right)_{4}^{-}$ & $\begin{array}{l}\mathrm{Y}\left(\mathrm{NO}_{3}\right)_{4}^{-} \rightarrow \mathrm{Y}\left(\mathrm{NO}_{3}\right)_{2}^{-}+2 \mathrm{NO}_{3} \\
\mathrm{Y}\left(\mathrm{NO}_{3}\right)_{4}^{-} \rightarrow \mathrm{NO}_{3}^{-}+\mathrm{Y}\left(\mathrm{NO}_{3}\right)_{3} \\
\mathrm{Al}\left(\mathrm{NO}_{3}\right)_{4}^{-} \rightarrow \mathrm{AlO}\left(\mathrm{NO}_{3}\right)_{3-}+\mathrm{NO}_{2}\end{array}$ \\
\hline $\mathrm{Al}\left(\mathrm{NO}_{3}\right)_{4}^{-}$ & $\begin{array}{l}\mathrm{Al}\left(\mathrm{NO}_{3}\right)_{4}^{-} \rightarrow \mathrm{AlO}_{2}\left(\mathrm{NO}_{3}\right)_{2}^{-}+2 \mathrm{NO}_{2} \\
\mathrm{Al}\left(\mathrm{NO}_{3}\right)_{4}^{-} \rightarrow \mathrm{NO}_{3}^{-}+\mathrm{Al}\left(\mathrm{NO}_{3}\right)_{3} \\
\mathrm{Ga}\left(\mathrm{NO}_{3}\right)_{4}^{-} \rightarrow \mathrm{GaO}\left(\mathrm{NO}_{3}\right)_{3}^{-}+\mathrm{NO}_{2}\end{array}$ \\
\hline $\mathrm{Ga}\left(\mathrm{NO}_{3}\right)_{4}^{-}$ & $\begin{array}{l}\mathrm{Ga}^{\prime \prime \prime}\left(\mathrm{NO}_{3}\right)_{4}^{-} \rightarrow \mathrm{Ga}^{\prime \prime}\left(\mathrm{NO}_{3}\right)_{3}^{-}+\mathrm{NO}_{3} \\
\mathrm{Ga}\left(\mathrm{NO}_{3}\right)_{4}^{-} \rightarrow \mathrm{NO}_{3}^{-}+\mathrm{Ga}\left(\mathrm{NO}_{3}\right)_{3} \\
\ln \left(\mathrm{NO}_{3}\right)_{4}^{-} \rightarrow \operatorname{lnO}\left(\mathrm{NO}_{3}\right)_{3}^{-}+\mathrm{NO}_{2}\end{array}$ \\
\hline $\ln \left(\mathrm{NO}_{3}\right)_{4}^{-}$ & $\begin{array}{l}\ln { }^{\operatorname{III}}\left(\mathrm{NO}_{3}\right)_{4}^{-} \rightarrow \operatorname{In}^{\prime \prime}\left(\mathrm{NO}_{3}\right)_{3}^{-}+\mathrm{NO}_{3} \\
\ln \left(\mathrm{NO}_{3}\right)_{4}^{-} \rightarrow \mathrm{NO}_{3}^{-}+\operatorname{In}\left(\mathrm{NO}_{3}\right)_{3}\end{array}$ \\
\hline
\end{tabular}

[24], too high to be accessible with the collision energies used here. Thus, we consider that the metal atom stays in the same oxidation state in the oxo-nitrate complex, with the $\mathrm{O}$ atom present as $\mathrm{O}^{-}$.

2. Reduction of metal atom with oxidation of nitrate to $\mathrm{NO}_{3}$.

$$
\begin{aligned}
& \mathrm{Cu}\left(\mathrm{NO}_{3}\right)_{3}^{-} \rightarrow \mathrm{Cu}^{\mathrm{I}}\left(\mathrm{NO}_{3}\right)_{2}^{-}+\mathrm{NO}_{3} \\
& \mathrm{Fe}^{\mathrm{III}}\left(\mathrm{NO}_{3}\right)_{4}^{-} \rightarrow \mathrm{Fe}^{\mathrm{II}}\left(\mathrm{NO}_{3}\right)_{3}^{-}+\mathrm{NO}_{3}
\end{aligned}
$$

The metal atom is reduced, while a nitrate ion is oxidized to $\mathrm{NO}_{3}$. The $\mathrm{NO}_{3}$ product molecule may also

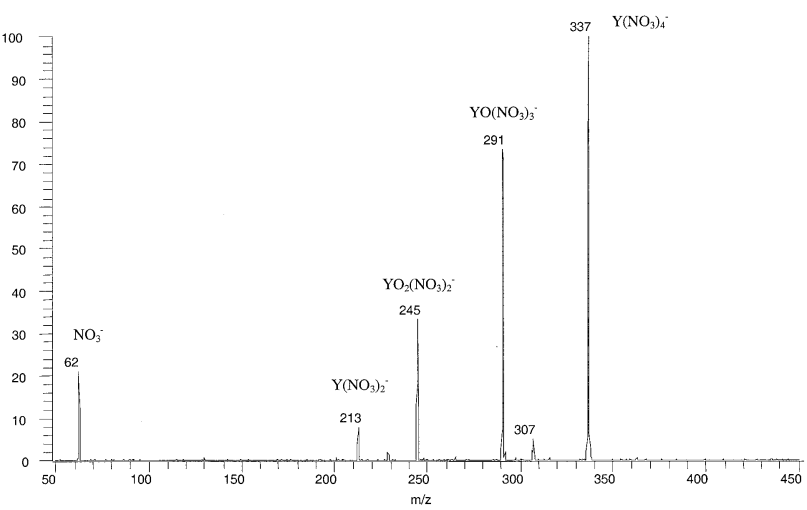

Figure 10. CID product spectrum of $\mathrm{Y}\left(\mathrm{NO}_{3}\right)_{4}^{-}(\mathrm{m} / \mathrm{z}=337)$, which fragments into $\mathrm{YO}\left(\mathrm{NO}_{3}\right)_{3}^{-}, \mathrm{YO}_{2}\left(\mathrm{NO}_{3}\right)_{2}^{-}, \mathrm{Y}\left(\mathrm{NO}_{3}\right)_{2}^{-}$, and $\mathrm{NO}_{3}^{-}$. The collision energy and pressure are $20 \mathrm{eV} \mathrm{lab}$ and $0.13 \mathrm{~Pa}$.

dissociate. Ions containing $\mathrm{Fe}^{2+}$ from solutions of $\mathrm{Fe}^{3+}$ were originally attributed to electrochemical reduction in solution at the ESI needle [19]. The fact that they can also be observed as CID products shows that such ions can be formed in the gas phase via this internal redox process. For the metals $\mathrm{In}^{3+}$ and $\mathrm{Ga}^{3+}$, this internal redox process can occur to yield $\mathrm{M}^{2+}$, detected as $\mathrm{M}^{\mathrm{II}}\left(\mathrm{NO}_{3}\right)_{3}^{-}$, even though the $2+$ oxidation state is not common in solution for these elements. In contrast, $\mathrm{Y}^{\mathrm{III}}\left(\mathrm{NO}_{3}\right)_{4}^{-}$yields $\mathrm{Y}^{\mathrm{I}}\left(\mathrm{NO}_{3}\right)_{2}^{-}$but not $\mathrm{Y}^{\mathrm{II}}\left(\mathrm{NO}_{3}\right)_{3}^{-}$(Figure $10)$.

3. Elimination of nitrate, generation of neutral metal nitrate complex.

$$
\mathrm{Fe}\left(\mathrm{NO}_{3}\right)_{4}^{-} \rightarrow \mathrm{NO}_{3}^{-}+\mathrm{Fe}\left(\mathrm{NO}_{3}\right)_{3}
$$

Complexes with one transition metal or Group 13 metal atom yield $\mathrm{NO}_{3}^{-}$as a minor CID product, in contrast to the Group 1 and 2 metals, where $\mathrm{NO}_{3}^{-}$is the only product ion.

\section{Threshold Kinetic Energy Measurements for $\mathrm{NO}_{3}^{-}$ $\rightarrow \mathrm{NO}_{2}^{-}+\mathrm{O}$}

Armentrout $[25,26]$ describes a number of validation criteria for determining the kinetic energy threshold for CID reactions [27-29]. These validation experiments are particularly important here because the present work is done with a commercial triple quadrupole MS built for chemical analysis, not for accurate thermochemical measurements [30-34].

One point is to evaluate the kinetic energy spread of the ion beam. Application of a stopping potential to the quadrupole rods indicates the ion energy spread is $\sim 0.7$ $\mathrm{eV}$ FWHM in the lab frame. A second point is to use a low collision gas pressure to minimize complications due to multiple collisions. For threshold measurements the inlet pressure is reduced from 0.13 to $0.026 \mathrm{~Pa}$. At $0.026 \mathrm{~Pa}$ the mean free path in the collision cell is estimated to be approximately $24 \mathrm{~cm}$, slightly longer than the ocotopole $(18 \mathrm{~cm})$. Thus, there still may be 


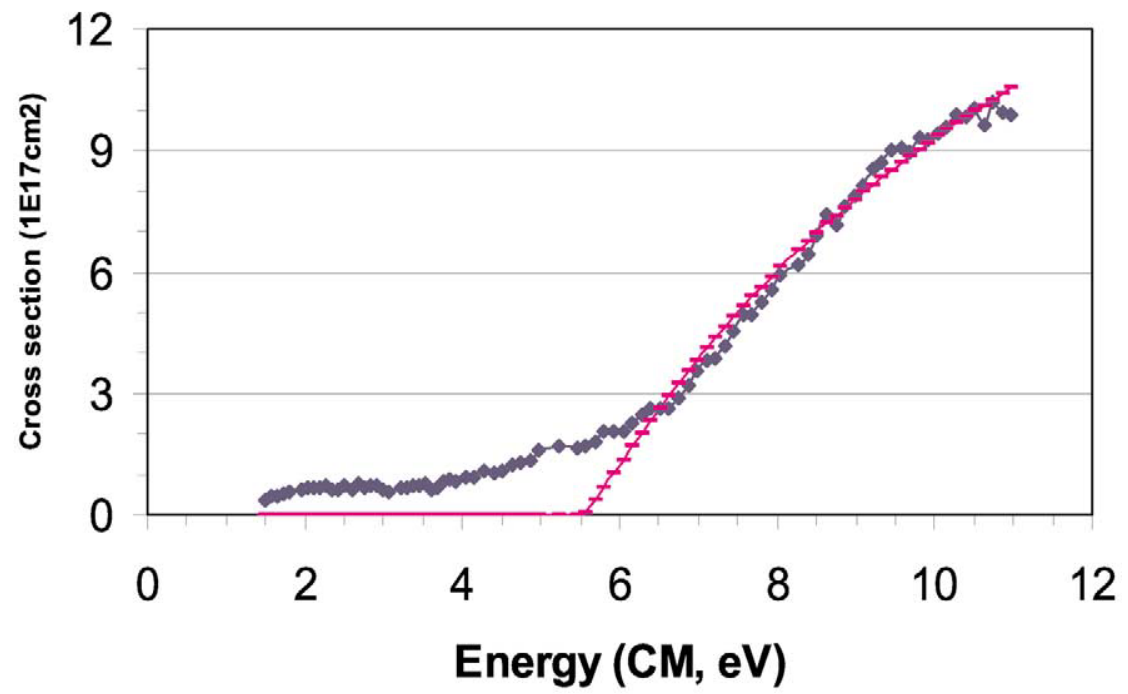

Figure 11. Cross section for $\mathrm{NO}_{3}^{-} \rightarrow \mathrm{NO}_{2}^{-}+\mathrm{O}$ versus collision energy in center of mass frame of reference. The diamonds are the direct experimental results, while the dashes are the converted experimental results using the procedure in reference [26]. $\mathrm{NO}_{2}^{-}$has an appearance threshold of 5.55 $\mathrm{eV}$.

some contribution from multiple collisions. Reducing the pressure attenuates the product ions to only a few percent of the parent ion signal, but measurable signals remain.

A third criterion is to calibrate the collision energy using a known process. We measure $\mathrm{CID}$ of $\mathrm{NO}_{3}^{-}, \mathrm{m} / \mathrm{z}=$ 62 , a species produced in the same fashion as the $\mathrm{M}\left(\mathrm{NO}_{3}\right)_{\mathrm{x}}^{-}$complexes of direct interest.

$$
\mathrm{NO}_{3}^{-} \rightarrow \mathrm{NO}_{2}^{-}+\mathrm{O}
$$

$\mathrm{D}_{0}\left(\mathrm{O}-\mathrm{NO}_{2}^{-}\right)=\mathrm{D}_{0}\left(\mathrm{O}-\mathrm{NO}_{2}\right)+\mathrm{EA}\left(\mathrm{NO}_{2}\right)-\mathrm{EA}\left(\mathrm{NO}_{3}\right)=$ $4.648+(-2.273)-(-3.937)=6.312 \mathrm{eV}[35,36] . \mathrm{NO}_{2}^{-}$is the only measurable product.

One plot in Figure 11 shows the measured cross section for Eq 10 as a function of collision energy in the center-of-mass frame of reference. These data are also converted to cross sections by the method described by Armentrout, [26, Eq 7] with $\sigma_{0}=18, n=1.1, \mathrm{E}_{0}=5.55$. The measured threshold for appearance of $\mathrm{NO}_{2}^{-}$is 5.55 $\mathrm{eV}$, lower than the calculated value by $0.76 \mathrm{eV}$. If anything, the apparatus underestimates the actual collision energy.

\section{Threshold Measurements for Daughter Ions from $\mathrm{Fe}\left(\mathrm{NO}_{3}\right)_{4}^{-}$}

Data obtained in single reaction mode for three CID products from $\mathrm{Fe}\left(\mathrm{NO}_{3}\right)_{4}^{-}$are shown in Figure 12. The thresholds for production of $\mathrm{FeO}\left(\mathrm{NO}_{3}\right)_{3}^{-}$and $\mathrm{Fe}\left(\mathrm{NO}_{3}\right)_{3}^{-}$ are very low, only 0.5 and $0.8 \mathrm{eV}$, respectively. Those for $\mathrm{FeO}_{2}\left(\mathrm{NO}_{3}\right)_{2}^{-}$and $\mathrm{FeO}\left(\mathrm{NO}_{3}\right)_{2}^{-}$are slightly higher, 1.5 and

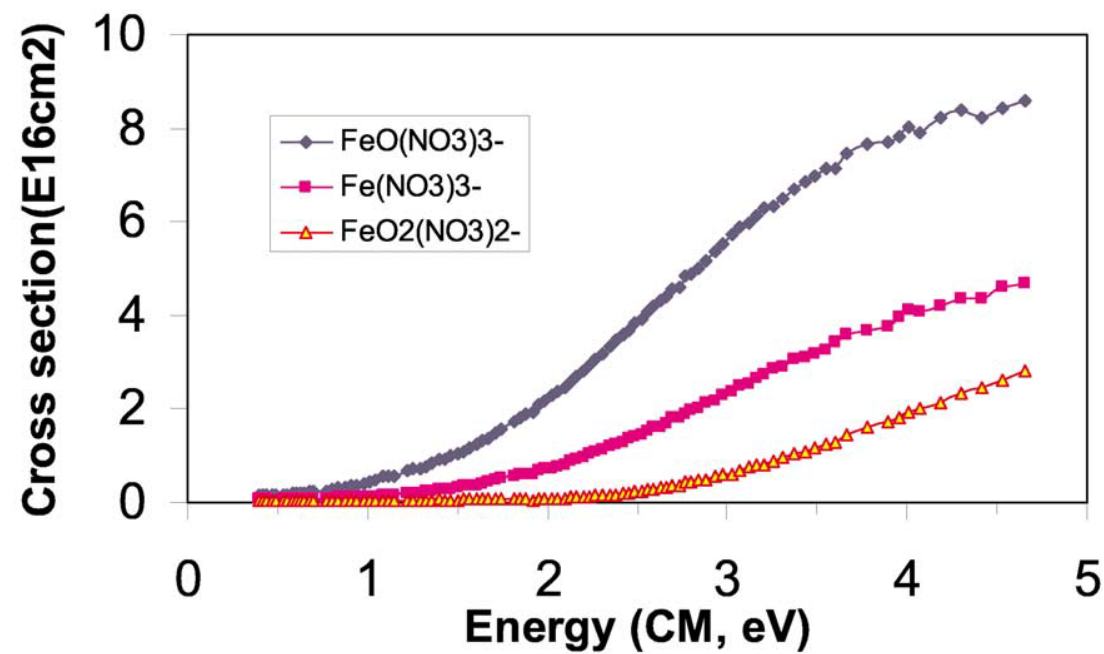

Figure 12. Measured cross sections for production of $\mathrm{FeO}\left(\mathrm{NO}_{3}\right)_{3}^{-}, \mathrm{Fe}\left(\mathrm{NO}_{3}\right)_{3}^{-}$, and $\mathrm{FeO}_{2}\left(\mathrm{NO}_{3}\right)_{2}^{-}$from $\mathrm{Fe}\left(\mathrm{NO}_{3}\right)_{4}^{-}$. The thresholds are only $0.5,0.8$, and $1.5 \mathrm{eV}$, respectively. 


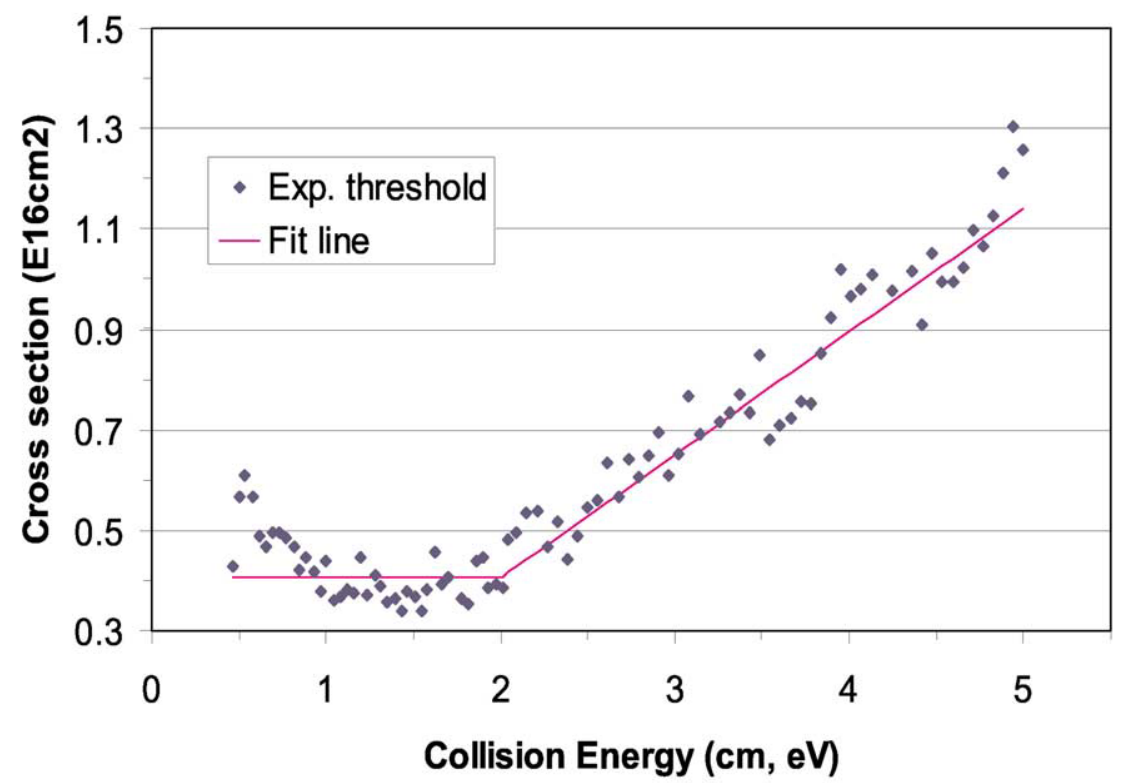

Figure 13. Measured cross sections for production of nitrate: $\mathrm{Fe}\left(\mathrm{NO}_{3}\right)_{4}^{-} \rightarrow \mathrm{NO}_{3}^{-}+\mathrm{Fe}\left(\mathrm{NO}_{3}\right)_{3}$. The threshold is $2.0 \mathrm{eV}$.

$1.8 \mathrm{eV}$ (data for the latter value are not shown). These values should be treated as approximations only, as the $0.76 \mathrm{eV}$ offset found from dissociation of $\mathrm{NO}_{3}^{-}$and other sources of error in the threshold measurements may be substantial. The main point is that low collision energy is sufficient to initiate these CID processes.

The threshold for elimination of $\mathrm{NO}_{3}^{-}$from $\mathrm{Fe}\left(\mathrm{NO}_{3}\right)_{4}^{-}$ is presented in Figure 13. Nitrate ion is a minor product, so there is more scatter in the plot than in those of previous figures. Nevertheless, the threshold for nitrate elimination (Eq 9) can be assigned to be approximately $2.0 \mathrm{eV}$. If the offset found for $\mathrm{NO}_{3}^{-} \rightarrow \mathrm{NO}_{2}^{-}+\mathrm{O}$ is added, the actual threshold is $2.76 \mathrm{eV}$, a reasonable value for a bond energy between a metal ion and an anionic ligand of moderate complexing strength.

\section{Thermochemical Considerations}

Consider the following thermodynamic cycle for conversion of $\mathrm{Fe}\left(\mathrm{NO}_{3}\right)_{4}^{-}$to $\mathrm{Fe}\left(\mathrm{NO}_{3}\right)_{3}^{-}$:

Most of the $\mathrm{Fe}-\mathrm{NO}_{3}^{-}$dissociation energies are not known, but the difference between the $D_{0}$ sums for the $\mathrm{Fe}^{3+}$ and $\mathrm{Fe}^{2+}$ nitrates can hardly be more than a few
$\mathrm{eV}$. Thus, the very large negative value for the third ionization energy of Fe should make this reaction highly exothermic. It is interesting that the ion $\mathrm{Fe}\left(\mathrm{NO}_{3}\right)_{4}^{-}$survives the collisions in the extraction process at all; it is, in fact, the most abundant ion from $\mathrm{Fe}^{3+}$ solutions under the conditions used.

\section{Conclusion}

The observations reported herein can be summarized as follows: (1) Complexation with nitrate can stabilize some highly reactive species with high internal energies. (2) Some metal nitrate ions undergo internal redox processes during CID, such as conversion of $\mathrm{M}^{3+}$ to $\mathrm{M}^{2+}$, even for elements like $\mathrm{In}^{3+}$ and $\mathrm{Ga}^{3+}$ that do not normally have lower oxidation states in solution. Presumably, such reductions are accompanied by oxidation of $\mathrm{NO}_{3}^{-}$to $\mathrm{NO}_{3}$. (3) Oxo ions are prominent from CID of triply charged metal nitrate complexes, as expected for "hard" metal cations. (4) Cluster ions with more than one metal atom are most evident for small metals with low charges. (5) The type of ion extraction device affects the species observed. Nitrate ions are

$$
\begin{array}{ll}
\quad \mathrm{Fe}\left(\mathrm{NO}_{3}\right)_{4}^{-} \rightarrow \mathrm{Fe}\left(\mathrm{NO}_{3}\right)_{3}+\mathrm{NO}_{3}^{-} & \mathrm{D}_{0}\left({ }^{-} \mathrm{O}_{3} \mathrm{~N}-\mathrm{Fe}\left(\mathrm{NO}_{3}\right)_{3}\right) \sim 2.76 \mathrm{eV} \\
\mathrm{Fe}\left(\mathrm{NO}_{3}\right)_{3} \rightarrow \mathrm{Fe}^{3+}+3 \mathrm{NO}_{3}^{-} & \Sigma \mathrm{D}_{0}\left(\mathrm{Fe}^{3+}-\mathrm{NO}_{3}^{-}\right)=? \\
\mathrm{Fe}^{3+}+\mathrm{e}^{-} \rightarrow \mathrm{Fe}^{2+} & -\mathrm{IE}\left(\mathrm{Fe}^{2+}\right)=-30.651 \mathrm{eV} \\
\mathrm{NO}_{3}^{-} \rightarrow \mathrm{NO}_{3}+\mathrm{e}^{-} & -\mathrm{EA}\left(\mathrm{NO}_{3}\right)=3.937 \mathrm{eV} \\
\frac{\mathrm{Fe}^{2+}+3 \mathrm{NO}_{3}^{-} \rightarrow \mathrm{Fe}\left(\mathrm{NO}_{3}\right)_{3}^{-}}{\mathrm{Fe}\left(\mathrm{NO}_{3}\right)_{4}^{-} \rightarrow \mathrm{Fe}\left(\mathrm{NO}_{3}\right)_{3}^{-}+\mathrm{NO}_{3}} & -\mathrm{\Sigma D}_{0}\left(\mathrm{Fe}^{2+}-\mathrm{NO}_{3}^{-}\right)=? \\
\end{array}
$$


apparently enhanced by the heated capillary interface. The ESI conditions may also play a role. (6) The CID reactions of $\mathrm{Fe}\left(\mathrm{NO}_{3}\right)_{4}^{-}$ions have low kinetic energy onsets of $\sim+0.5$ to $2 \mathrm{eV}$ and are expected to be exothermic.

\section{Acknowledgments}

Ames Laboratory is operated by Iowa State University for the U.S. Department of Energy, contract no. W-7405-Eng-82. This work was supported by the Chemical and Biological Sciences Program, Office of Basic Energy Sciences, Division of Chemical Sciences. The authors thank L. Huang and Bayer Company for donating the triple quadrupole MS, Bruce Thomson and Perkin Elmer Sciex for providing access to a triple quadrupole instrument with a curtain gas interface, and James Espenson and Gabor Lente for valuable discussions.

\section{References}

1. Yamashita, M.; Fenn, J. B. Electrospray Ion Source. Another Variation on the Free-Jet Theme. J. Phys. Chem. 1984, 88, 4451-4459.

2. Kebarle, P.; Tang, L. From Ions in Solution to Ions in the Gas Phase-The Mechanism of Electrospray Mass Spectrometry. Anal. Chem. 1993, 65, 972A-986A.

3. Chait, B. T.; Kent, S. B. H. Weighing Naked Proteins: Practical, High-Accuracy Mass Measurement of Peptides and Proteins. Science 1992, 257, 1885-1894.

4. Cole, R. B. Electrospray Ionization Mass Spectrometry. John Wiley and Sons: New York, 1997; pp 527-570.

5. Burlingame, A. L.; Boyd, R. K.; Gaskell, S. J. Mass Spectrometry. Anal. Chem. 1996, 68, 599-652.

6. Colton, R.; D'Agostino, A.; Traeger, J. C. Electrospray Mass Spectrometry Applied to Inorganic and Organometallic Chemistry. Mass Spectrom. Rev. 1995, 14, 79-106.

7. Stewart, I. I. Electrospray Mass Spectrometry: A Tool for Elemental Speciation. Spectrochim. Acta Part B 1999, 54, 16491695.

8. Henderson, W.; Nicholson, B. K.; McCaffrey, L. J. Applications of Electrospray Mass Spectrometry in Organometallic Chemistry. Polyhedron 1998, 17, 4291-4313.

9. Feng, R.; Castelhano, A. L.; Billedeau, R.; Yuan, Z. Y. Study of Noncovalent Enzyme-Inhibitor Complexes. Stoichiometry of Matrilysin by Electrospray Ionization Mass Spectrometry. J. Am. Soc. Mass Spectrom. 1995, 6, 1105-1111.

10. Bayer, E.; Bauer, T.; Schmeer, K.; Bleicher, K.; Maier, M.; Gaus, H. J. Analysis of Double-Stranded Oligonucleotides by Electrospray Mass Spectrometry. Anal. Chem. 1994, 66, 3858-3863.

11. Yu, X. L.; Wojciechowski, M.; Fenselau, C. Assessment of Metals in Reconstituted Metallothioneins by Electrospray Mass Spectrometry. Anal. Chem. 1994, 66, 1355-1359.

12. McLafferty, F. W.; Guan, Z.; Haupts, U.; Wood, T. D.; Kelleher, N. L. Gaseous Conformers of Cytochrome c. J. Am. Chem. Soc. 1998, 120, 4730-4732.

13. He, F.; Hendrickson, C. L.; Marshall, A. G. Unequivocal Determination of Metal Atom Oxidation State in Naked Heme Proteins: $\mathrm{Fe}(\mathrm{III})$ myoglobin, $\mathrm{Fe}(\mathrm{III})$ cytochrome c, Fe(III)cytochrome b5, and Fe(III)cytochrome b5 L47R. J. Am. Soc. Mass Spectrom. 2000, 11, 120-126.

14. Sharp, B. L.; Sulaiman, A. B.; Taylor, K. A.; Green, B. N. Observations on the Use of Ion Spray Mass Spectrometry for Elemental Speciation in Aqueous Solutions Without Recourse to Chromatography. J. Anal. Atomic Spectrom. 1997, 12, 603609.
15. Cheng, Z. L.; Siu, K. W. M.; Guevremont, R.; Berman, S. S. Electrospray Mass Spectrometry: A Study on Some Aqueous Solutions of Metal Salts. J. Am. Soc. Mass Spectrom. 1992, 3, 281-288.

16. Cheng, Z. L.; Siu, K. W. M.; Guevremont, R.; Berman, S. S. Solvent-Derived Metal Oxides in Electrospray Mass Spectrometry of Metal Salt Solutions. Org. Mass Spectrom. 1992, 27, 1370-1376.

17. Agnes, G. R.; Horlick, G. Electrospray Mass Spectrometry as a Technique for Elemental Analysis: Preliminary Results. Appl. Spectrosc. 1992, 46, 401-406.

18. Blades, A. T.; Jayaweera, P.; Ikonomu, M. G.; Kebarle, P. First Studies of the Gas Phase Ion Chemistry of $\mathrm{M}^{3+}$ Metal Ligand Complexes. Int. J. Mass Spectrom. Ion Processes 1990, 101, 325-336.

19. Mollah, S.; Pris, A. D.; Johnson, S. K; Gwizdala, A. B., III; Houk, R. S. Identification of Metal Cations by Electrospray Mass Spectrometry in the Negative Ion Mode. Anal. Chem. 2000, 72, 985-991.

20. (a) Viggiano, A. A. In Situ Mass Spectrometry and Ion Chemistry in the Stratosphere and Troposphere. Mass Spectrom. Rev. 1993, 12, 115-137. (b) Viggiano, A. A.; Hunton, D. E. Airborne Mass Spectrometers: Four Decades of Atmospheric and Space Research at the Air Force Research Laboratory. J. Mass Spectrom 1999, 34, 1107-1129.

21. Finlayson-Pitts, B. J.; Pitts, J. N., Jr. Chemistry of the Upper and Lower Atmosphere. Theory, Experiment, and Applications. Academic: San Diego, 2000, Chap VII E and p 285.

22. Zhao, X.; Yinon, J. Forensic Identification of Explosive Oxidants by Electrospray Ionization Mass Spectrometry. Rapid Commun. Mass Spectrom. 2002, 16, 1137-1146.

23. Houk R. S., Thomson B. A. unpublished results.

24. Huheey, J. E. Inorganic Chemistry: Principles of Structure and Reactivity. Harper: New York, 1972; p 46.

25. Armentrout, P. B. Thermochemical Measurement by Guided Ion Beam Mass Spectrometry. Advances in Gas Phase Ion Chemistry, Vol. 1; In Adams, N. G.; Babcock, L. M., Eds.; JAL: Greenwich, 1992; pp 83-119.

26. Armentrout, P. B. Mass Spectrometry-Not Just a Structural Tool: The Use of Guided Ion Beam Tandem Mass Spectrometry to Determine Thermochemistry. J. Am. Soc. Mass Spectrom. 2002, 13, 419-434.

27. Muntean, F.; Armentrout, P. B. Guided Ion Beam Study of Collision-Induced Dissociation Dynamics: Integral and Differential Cross Sections. J. Chem. Phys. 2001, 115, 1213-1228.

28. Armentrout, P. B. The Kinetic Energy Dependence of IonMolecule Reactions: Guided Ion Beams and Threshold Measurements. Int. J. Mass Spectrom. 2000, 200, 219-241.

29. Rodgers, M. T.; Ervin, K. M.; Armentrout, P. B. Statistical Modeling of Collision-Induced Dissociation Threshold. J. Chem. Phys. 1997, 106, 4499-4508.

30. Rodgers, M. T.; Armentrout, P. B. Collision-Induced Dissociation Measurements on $\mathrm{Li}^{+}\left(\mathrm{H}_{2} \mathrm{O}\right)_{n}, n=1-6$ : The First Direct Measurement of the $\mathrm{Li}^{+}-\mathrm{OH}_{2}$ Bond Energy. J. Phys. Chem. A 1997, 101, 1238-1249.

31. Andersen, A.; Muntean, F.; Walter, D.; Rue, C.; Armentrout, P. B. J. Phys. Chem. A 2000, 104, 692-705.

32. Ariston, N.; Armentrout, P. B. Collision-Induced Dissociation of Vanadium Monoxide Ion. J. Phys. Chem. 1986, 90, 5135-5140.

33. Armentrout, P. B.; Hales, D. A.; Lian, L.; Duncan, M. A., Eds.; In Advances in Metal and Semiconductor Clusters; Vol. II. JAI: Greenwich, 1994; pp 1-39.

34. Rodgers, M. T.; Armentrout, P. B. Noncovalent Metal-Ligand Bond Energies as Studied by Threshold Collision-Induced Dissociation. Mass Spectrom. Rev. 2000, 19, 215-247.

35. Ervin, K. M.; Ho, J.; Lineberger, W. C. Ultraviolet Photoelectron Spectrum of $\mathrm{NO}_{2}^{-}$. J. Phys. Chem. 1988, 92, 5405-5412. 
36. Weaver, A.; Arnold, D. W.; Bradforth, S. E.; Neumark, D. M. Examination of the ${ }^{2} \mathrm{~A}_{2}$, and ${ }^{2} \mathrm{E}^{\prime \prime}$ States of $\mathrm{NO}_{3}$ by Ultraviolet
Photoelectron Spectroscopy of $\mathrm{NO}_{3}^{-}$. J. Chem. Phys. 1991, 94 1740-1751. 